\title{
Molnár Edina
}

\section{A pszichológia filozófiai-társadalomtudományi vonalának kibontakozása Magyarországon az 1900-as években}

Edina Molnár: The Conception of the Philosophical and Social Scientific Trend of Psychology in Hungary in the 1900s

\begin{abstract}
In Hungary, the science of psychology separated early in the XX. century using three trends: the tradition of social science emerged from the philosophy, the psychoanalytic trend was born in the healing and the natural science in the children-experiments. Famous representatives of the philosophical trend were Szüts, Ribot, Pikler, Leopold, Kornis, Posch. We can recognise the concepts of the human inner processes, the cognition and the soul activity of the early psychology from their publications.
\end{abstract}

Keywords: scientific psychology, philosophical trend, soul activity

\section{ÖSSZEFOGLALÓ}

Magyarországon a tudományos pszichológia a XX. század elején kezdett kibontakozni, három irányvonal mentén: a társadalomtudományi hagyomány a filozófiából, a pszichoanalitikus vonal a gyógyításból és a természettudományi trend a gyermekekkel végzett kísérletekből fejlődött ki. A filozófiai vonal híres képviselői Szüts, Ribot, Pikler, Leopold, Kornis, Posch. Az emberi belső folyamatok, a gondolkodás és a lelki tevékenységek korai pszichológiai koncepcióit az ő publikációikon keresztül ismerhetjük meg.

Kulcsszavak: tudományos pszichológia, filozófiai megközelítés, lelki tevékenység

\section{BEVEZETÉS}

A pszichológia Magyarországon kb. az 1900-as években kezdett külön tudománnyá válni. A kezdeti szárnybontogatás három ágon indult el. A filozófiai-társadalomtudományi vonal, a pszichoanalitikus hagyomány és a kísérletitermészettudományos ág különböző alap.- állásokból közelítettek az emberhez, ebből következően a különböző ágaknak elkötelezett pszichológusok más-más emberképpel dolgoztak.

A második világháború kezdetéig - figyelembe véve a társadalmi, történelmi és tudományos aspektusokat - három idői struktúrára tagolható a pszichológiai gondolkodás fejlődése.

Megvizsgálva a korabeli pszichológiai publikációkat és szem előtt tartva a fenti megállapításokat, felrajzolhatók az emberképben bekövetkezett változások.

A magyar pszichológiát kutatási alapként tekintve egyszerúnek tûnik az a kérdés, hogy milyen időponttól kezdve történjen az irodalom áttekintése. Valóban meghatározható egy dátum, amely az intézményesülés kezdetét jelöli, ez azonban nem zárja ki azt, hogy már e dátumot megelőzően is voltak pszichológiai témájú publikációk.

Ha magából a pszichológiából nem lehet kiindulni a kezdési dátum meghatározásában, 
akkor magától értetődő a történelmi korszak és a politikai, kulturális élet valamely pontját körülhatárolni, amely magában foglalja a pszichológia intézményesülésének időszakát is.

Ez a történelmi időszakasz az Osztrák-Magyar Monarchiára esik, az 1867-es kiegyezés utáni időszakra, amelynek közel fél évszázados fennállása nyilvánvalóan meghatározta a társadalom és a társadalomtudományok fejlődését, illetve magában foglalta a magyar pszichológia, mint tudomány létrejöttét.

$\mathrm{Az}$ osztrák és magyar nemzet sajátságos elrendeződése azonban azt eredményezte, hogy a kialakulóban lévő tudomány anyanyelve a német, illetve fokozatosan a magyar lesz. Ez a nyelvi váltás egyben jelzi a magyar pszichológia öntudatra ébredését is.

A fenti kérdések megválaszolására azt a megoldást választottam, hogy a történelmipolitikai és a tudományfejlődési eseményeket ötvözve három szakaszra bontom a vizsgálandó időszakot. Az első szakasz az 1867-es osztrákmagyar kiegyezés „boldog békeidős” szakasza (Romsics, 2002), az első világháború kezdetéig. A második szakasz az első világháborús évek, és az azt követő normalizálódási periódus, 1928-ig. Ez a dátum egy tudományfejlődési állomás, ekkor alakult meg a Magyar Psychologiai Társaság. Végül a harmadik szakasz 1928-tól tart a második világháború kezdetéig.

Minden szakaszban először a történelmipolitikai és kulturális hátteret foglalom össze, amely valamilyen befolyással volt a társadalomtudományokra, ezután az adott időszak neves pszichológusainak gondolatait írom le, amelyből az alakuló emberképre következtetni lehet, végül magát az emberképet rajzolom fel. A három korszak részletezését követően az egyes korszakok emberképeit hasonlítom össze.

A kutatás korpusza táblázatos formában a következőképpen alakul:

\begin{tabular}{|c|c|c|c|}
\hline & $\begin{array}{l}\text { Filozófiaiés } \\
\text { társadalomtudományi } \\
\text { hagyomány }\end{array}$ & $\begin{array}{l}\text { Pszichoanalitikus } \\
\text { hagyomány }\end{array}$ & $\begin{array}{l}\text { Kísérleti pszichológiai } \\
\text { (természettudományos) } \\
\text { hagyomány }\end{array}$ \\
\hline $\begin{array}{l}\text { Kb. a századforduló- } \\
\text { tól az I. világháborúig } \\
(1900-1914)\end{array}$ & $\begin{array}{l}\text { Szüts Istvány } \\
\text { Ribot, Th. } \\
\text { Pikler Gyula } \\
\text { Leopold Lajos } \\
\text { Kornis Gyula } \\
\text { Posch Jenő }\end{array}$ & FerencziSándor & $\begin{array}{l}\text { Ballai Károly } \\
\text { A Ranschburg-iskola } \\
\text { kiadványánakI-II. kötete }\end{array}$ \\
\hline $\begin{array}{l}\text { Az l. világháborútól a } \\
\text { Magyar Pszichológiai } \\
\text { Társaság } \\
\text { megalakulásáig } \\
\text { (1914-1928) }\end{array}$ & $\begin{array}{l}\text { Pikler Gyula } \\
\text { Alexander Bernát } \\
\text { Farkas Geiza } \\
\text { Kornis Gyula } \\
\text { Posch Jenő }\end{array}$ & Róheim Géza & $\begin{array}{l}\text { Gergó Endre } \\
\text { Ranschburg Pál } \\
\text { A Ranschburg-iskola } \\
\text { kiadványaának III-V. kötete } \\
\text { Révész Géza }\end{array}$ \\
\hline $\begin{array}{l}\text { A Társaság } \\
\text { megalakulásá-tól a II. } \\
\text { világháborúig } \\
\text { (1928-1938) }\end{array}$ & Spranger Eduárd & FerencziSándor & $\begin{array}{l}\text { Harkai-Schiller Pál } \\
\text { Révész Géza } \\
\text { A Magyar Pszichológiai Szemle I- } \\
\text { XI. kötete }\end{array}$ \\
\hline
\end{tabular}

Jelen tanulmány témája a fenti táblázat sötéttel jelzett kockája, tehát a filozófiai és társadalomtudományi pszichológiai hagyomány kezdetei, az első világháború kezdetéig bezárólag.

\section{Történelmi és kulturális háttér}

A magyar pszichológia kialakulása egybeesett az Osztrák-Magyar Monarchia válságával. A történelmi-politikai helyzet által felkorbácsolt polgári radikális gondolkodás és a szociális mozgalmak felívelése párhuzamosan haladt a pszichológia és a szociológia első nagy divathullámával. (Pataki, 1977)

Az 1900-as évek elején, Magyarországon három vonalon kezdett kibontakozni a pszichológia. (Pléh, 1998) Az akkoriban a Révész Géza vezetésével megalakult Magyar Filozófiai Társaság és a társaság Alexander Bernát által indított folyóirata jóvoltából megszaporodtak 
az olyan filozófiai publikációk, amelyek témája a lélektan volt. Beszivárogtak a felsőoktatásba is az ilyen irányú előadások és szemináriumok, amelyeket a filozófiai tanszékek keretei között tartottak. A kor filozófusai négy kérdésre keresték a választ. (Bárkán, 1985) A gondolkodás pszichológiai folyamatai és a logika törvényszerűségei közötti különbségből adódott az első kérdés: honnan származik a logika érvényessége és kötelező ereje. Hasonlóan ehhez, a második kérdés is egy különbség felismeréséből fakadt: a kísérleti lélektan és a megismerés elmélete közötti szakadékot áthidalva hogyan lehet egy általános tudományrendszert kialakítani. A harmadik kérdés a mindennapi élet és a tudományos megismerés logikája közötti különbözőségre épült. Végül a negyedik kérdés az ember társadalmi létének problémája körül mozgott: hogyan hat a társadalmiság a megismerésre.

A második vonal a pszichoanalízis elterjedését és különböző alkalmazásait foglalja magában a kultúra, a múvészet, az irodalom és az orvoslás területén. A pszichoanalízis korai megjelenésétől a második világháborúig a haladó társadalmi törekvések rokonszenvét élvezte, ugyanakkor ellenérzéseket váltott ki a hivatalos tudomány múvelőiből.

Végül a harmadik vonal a pszichológia intézményesülése a nevelés és a fogyatékosgondozás területén. $\mathrm{Az}$ első magyar pszichológiai laboratóriumot Ranschburg Pál alapította 1902-ben a Mosonyi utcai kisegítő iskola falai között, „Gyógypedagógiai Intézetekhez kapcsolt Psychológiai Laboratórium" néven (Pataki, 1977), ahol a neveléspszichológia alkalmazott területén folytak éveken keresztül meghatározó kutatások. (Id. a fenti táblázatot)

A magyar pszichológia fejlődésére nagy hatással voltak a kulturális és politikai összefüggések, amelyek az említett három vonal tartós párhuzamosságát okozták, ahelyett, hogy kialakult volna egy egységes hivatalos álláspont a tudományon belül. (Pléh, 1998) A politikai tisztogatások és a kivándorlások miatt nem alakulhattak ki hagyományos tanár-diák kapcsolatok, kivéve a pszichoanalitikus vonalat. $\mathrm{Ez}$ azért lett volna fontos, mert minden korszakban meghatározó az informális hálózatok szerepe, fontos a képzésben, a szakmai előrehaladásban és a szakmai közvélemény kialakításában egyaránt.

Szintén meghatározó volt a pszichológia fejlődésére nézve az a tény, hogy önmagát mindig úgy definiálta, mint olyan társadalomtudományt, amely nem csak önmagáért való, hanem a társadalom jólétéért is felelős. Ez a hozzáállás azonban azt eredményezte, hogy a pszichológusok túlzottan figyelembe vették az aktuális politikai életet, így nem jöhetett létre egy egészséges versengés a tudományon belül.

A politikai élet túlzott figyelembe vételének természetesen megvolt az oka, hiszen szükséges volt a tudomány intézményesüléséhez a központi támogatás, ugyanakkor feszültséget okozott az ezzel szemben fellépő függetlenségi igény.

Másrészt azonban az aktuális politikai és társadalmi élet figyelemmel tartása lehetővé tette az akadémikus és alkalmazott területek összeegyeztetését, a közöttük lévő állandó váltakozás fennmaradását.

Mindezen okok miatt a magyarországi pszichológiára még inkább jellemző az a tény, hogy a kutatásban felbukkanó kérdésfeltevések újra és újra bekerülnek a tudomány főáramába, amely egy ciklikus folyamatot eredményez. A ciklikusság nem engedi meg az egyirányú fejlődést, ez azonban nem jelenti azt, hogy nincs fejlődés. A tudomány fejlődése nem a fő kérdések körüli koncentrikus körökben zajlik, inkább egy spirálban, amely magában rejti a többirányú fejlődés lehetőségét.

\section{A filozófiai-társadalomtudományi hagyomány pszichológusainak gondolatai az emberről}

\section{1. Az intézményesülés előtti magyar nyelvú pszichológia}


Az 1800-as évek elején Szüts Istvány tartott egy lélektani előadást, „Tapasztalásbéli emberlélekértékség" címmel latinul, amelyet egyik tanítványa lefordított magyarra. (Joó, 1929) Az előadás, miután tisztázza a pszichológia és a pneumatológia közötti különbséget - az előbbi az emberi lélek, az utóbbi az ember és állat közötti különbségek tudománya -, valamint a lélektanban használatos módszereket, úgy mint racionális és empirikus módszer, az emberi lélek jellemzőivel foglalkozik.

Szüts szerint az emberi léleknek három képessége van, az ábrázoló, azaz képzetalkotó, az érző és a kívánó-utáló képesség. Ehhez hozzákapcsolható az ítélő-okoskodó képesség is. „....az Esmérés' felső tehettségéhez e' három tartozik: 1ör Az Értelem. 2or. Az Itélettétel. 3or. Az Okosság", ezen képességek tárgyalása azonban a logika körébe tartozik. A lélek aktív, „önként való mozgása” van, szemben a testtel, ami passzív, „mozgatlanság” jellemzi, a kettó azonban egymás nélkül nem létezik, ugyanis a lélek eszköze a test, különösen az agy és az idegek. A lélek aktivitása eredményezi, hogy az ember bizonyos abban, hogy van lelke.

A lélek aktivitásának feltételei a lélek tehetségei. Az aktivitás a lelki tevékenységet jelenti, tulajdonképpen a tevékenység lehetőségének a feltétele a tehetség, magának a tevékenységnek a feltétele a lélek ereje. A lelki tehetségek kétfélék lehetnek, „törsökösek”, azaz örököltek és „származók”.

Szüts részletesen leírja a képalkotás menetét, amelyben a lélek tehetségei és ereje is közremúködnek. A képalkotáshoz szükséges egy tárgy, az alany és a tárgy képe. A folyamat akkor jöhet létre, ha a tárgy megfelelő erővel hat az érzékszervekre. A tárgy materiális változást idéz elő, azaz impressziót az érzékszervekben, ez az impresszió közöltetik a lélekkel, amely változást eredményez, ez a percepció. A tárgyban rejlő jelek tudósítását egyébként a tudat egyik funkciója biztosítja, a megkülönböztetés. A tudat másik funkciója az ábrázolás, amelynek elemei a megkülönböztetés során tapasztalt tárgyi jelek. Végül a lélek tevékenysége a tárgy észrevett jegyeit összefoglalja, majd képpé alkotja.

„....az érzés nem más, hanem ollyan ábrázolás, mellyet az előzmények [tárgyak] bényomásaik által bennünk a' Lélekben támasztanak." Tehát Szüts szerint az érzés tulajdonképpen az ábrázolás egy másik elnevezése. Ugyanakkor az érzés szubjektív voltát és pontatlanságát taglalja, ami ellentétben áll az előbbi ábrázolás pontosságával.

Belső érzékelésről beszél, ami tulajdonképpen az öntudat, a képzelő tehetséget, költői tehetséget elemzi, amely a képzetek szabad kezelését jelenti, végül az emlékezet különböző fajtáiról ír.

Fontos helyet foglal el az előadásban az asszociáció elmélete. Szüts szerint két oka lehet az asszociációnak, az egyik fizikai, amely az idegek közelségén és egyszerre történő múködésén alapul, a másik pszichológiai, amelynek eredménye, hogy az egyszerre keletkezett képzetek egységet alkotnak. Ebből kiindulva a képzettársítás törvényeit is ismerteti.

Ribot 1896-ban magyarra fordított „Lelki átöröklés" c. múve részletesen leírja az öröklés minden típusát és múködésének hogyanját. Bár a szerző nem magyar, mégis azért tartottam fontosnak megemlíteni, mert nagyon sok magyar pszichológus hivatkozott rá. A könyv bevezetésében olvashatjuk az öröklés definícióját: „Az átöröklés az a biologiai törvény, a melynél fogva minden élő lény arra törekszik, hogy magát utódaiban ismételje; ez az a fajra nézve, a mi a személy-azonosság az egyedre nézve."

A könyv első része megvizsgálja és összefoglalja az emberi lélek különböző összetevőinek öröklődését, kezdve az ösztönöktől az értelemen keresztül a nemzeti jellemig. Minden egyszerű ösztön örökölt szokás, a bonyolultabb ösztönök pedig az egyszerūekből állnak, tehát azok is öröklődnek. Az ösztönökön túl a szerzett változások is örökölhetők, azonban ezeknek 3-4 
Molnár Edina: A pszichológia filozófiai-társadalomtudományi vonalának kibontakozása ...

nemzedékre van szükségük a megszilárduláshoz.

$\mathrm{Az}$ érzékelő képességek átöröklése agybeli öröklés, az emlékező tehetség és a szokások viszont alacsonyabb rendúek, mint az akarat vagy a gondolkodás, mégis valószínú, hogy átöröklődnek. Az értelem átöröklését a gyakori zenész és festőmúvész családok vizsgálatából vezeti le a szerző. Az érzelmek és szenvedélyek szintén öröklődnek, ahogy olyan társadalmi jelenségek is, amelyek a történelemben és a nemzeti jellemben adottak. Végül a beteges lelki állapotok - szintén a családi vizsgálatokból kiinduló következtetések alapján - ugyancsak öröklődnek.

A könyv második része az átöröklés törvényeit veszi számba. Az átöröklés legegyszerübb esete az egyenes öröklés, például amikor a gyerek az egyik szülőre hasonlít. A túlsúly törvénye a jellemvonások esetén jelenik meg, amikor a fiú az apára, a lány az anyára üt. A közvetett öröklést atavismusnak nevezi Ribot, ilyenkor a gyermek egy korábbi ősre hasonlít. A következő öröklés a megfelelő életkorban jelentkező, amely tulajdonképpen az érés folyamatához kapcsolódik. A befolyási átöröklés nagyon ritka, ekkor a feleség első férjének valamely tulajdonsága a második férj gyerekében nyilvánul meg. Az öröklési törvényeket statisztikai kísérletekkel támasztja alá a szerző, amely természetesen nem zárja ki a kivételeket sem.

A könyv harmadik része az átöröklés lélektani, erkölcsi és társadalmi következményeit mutatja be, végül a befejezésben megfogalmazódik az átöröklésre vonatkozó hipotézis: az átöröklés faji determinizmus.

2. 2. Az intézményesülés utáni magyar nyelvú pszichológia az első világháború kezdetéig

Pikler Gyula az életfolyamatok célszerűségéből indult $\mathrm{ki}$, és ennek a célszerúségnek a belátásából. Az egyén kognitív konstrukciói, illetve a társadalmi szerveződések is erre épülnek. (Bárkán, 1985)
Pikler modellje szerint az életfolyamatokból fakadó önfenntartási törekvések következtében a szervezet aktív hatást gyakorol a környezetére, ahonnan visszahatások jönnek létre. Ezek újabb hatásokat váltanak ki, ezek a "másodlagos folyamatok", amelyek lehetnek közömbösek, építőek, gátlóak vagy erősítők. Ez vezet a szelektív észrevételhez, amely mindig két állapot közötti különbséget tükröz vissza. Észlelés csak úgy történhet, hogy a tárgy ellentétét is egyúttal észrevesszük, tehát az észrevevésben mindig ellentétes tendenciák mutatkoznak meg. $A z$ észlelés aktív összetevőinek eredményeként működik egy „tagadás az érzékelésben” elv, amely a kontraszt, az utókép, stb. ellenfolyamatokért felelős. (Pléh, 1998) Így választódnak ki az életfolyamatokban az "eszméleti“, azaz tudatos, ill. az „eszméletlen“, vagyis tudattalan történések.

Az 1909-es „A lélektan alapelvei: az élmény megmaradása és ellentétessége" c. tanulmánya szerint a megismerés középpontjában álló élménynek két tulajdonsága van: stabil és megmaradásra törekszik. A lélek az élmény és az anticipáció, azaz „várás” ellentétességében különbséget észlel, amely a magasabb rendú megismerési formák, mint a képzet, az emlék, a fogalom, az ítélet kialakításának alapjává válik. A modell dinamikus jellegú, ellentétben a reflexológiával. (Bárkán, 1985)

„A lelki élet fizikája. A pszikhofiziológia teljes rendszerének vázlata és az uralkodó tan kritikája" címmel publikált tanulmányában (1901) a lelki életet egésznek tekinti, szemben az elterjedt nézettel, amely szerint a lélek funkciói különválaszthatók a megismerésre, az érzésre és az akaratra. Továbbviszi az oszthatatlanság gondolatát, amikor azt mondja, hogy a testi és a lelki élet egy és ugyanaz.

1910-ben adták ki Pikler „A lelki élet alaptörvényei. Az eszmélet helye a természetben" címú könyvét, amelyben a meggyőződésekről és az egységességről gondolkodik tovább: „A lélektannak...van egy...alapigazsága, csakhogy ezt ma nemcsak a 
múveletlen ember nem ismeri, hanem a lélektan tudományával foglalkozók sem, néhány kevés kivételével, vagy legalább nem teszik a tudomány alapjává. Ez az igazság a következő: Ha egy tényt, pld. egy házat, vagy egy hegedühangot ismerünk, nemcsak az a meggyőződés van meg bennünk, hogy a tény abban az időpontban és azon a helyen fennállott, illetőleg fennáll, amely időpontban és helyen megismertük, illetőleg megismerjük, hanem az a meggyőződés is, hogy ez a tény minden időben, minden helyen, szóval általánosan, egyetemesen, korlátlanul fennáll." A lelki élet általános és egyetemes jellegét egyúttal a tudomány tárgyát alkotó jelenség átfogó és mindenre kiterjedő magyarázatára is átviszi. (Pataki, 1977)

Posch Jenő a lelki élet egységének lehetőségét a motoros szerveződésben látja. A magasabb lelki funkciók is mind a motoros szerveződésből származnak. (Pléh, 1998) A cselekvés bázis jellege jelenik meg az 1913-ban publikált „Játék, múvészet és munka" c. múvében, amelyben az emberi és az állati cselekvés közös nevezőjét keresi: „Amit teszek, ezért teszem, mert maga az, amit teszek, tetszik nekem."

A címben szereplő mindhárom múködés egységesen cselekvés, és a fenti idézet a jeligéje. Minden cselekvés a cselekvő személy valamely szükségletét orvosolja. A három cselekvés indítéka három különböző dolog, a testi kellemes, az esztétikai szép és a morális jó.

A három cselekvés részletes elemzése után Posch megállapítja, hogy a cselekvések elnevezése nem pszichológiailag leíró fogalom, hanem értékmegállapító. A játék és a múvészet értéke nem egyezik meg a munka értékével, például a játék szó gyakran csak metaforikus, mint a szerencsejáték vagy a tornajáték esetében. A játék végső célja a cselekvő vagy a megfigyelő számára komikusnak tűnik. A munkatevékenység mellett pedig nem beszélhetünk művésztevékenységről.

Leopold Lajos „A presztizs” című 1912-es művében, reagálva a korabeli utánzáselméletek egyszerűségére (Pléh, 1998), bevezet egy új fogalmat, amely szerinte a társas befolyást meghatározó jelenség leírására alkalmas. A presztízs árnyaltabb módon múködik és az élet minden területén meghatározóbb jelenség, mint az utánzás. Definíció szerint „Ha valakinek presztizse van előttünk, ez azt jelenti, hogy iránta vagy a vele asszociáltak iránt érzett érdeklődésünk, hajlamunk, ösztönünk, vágyunk oly érzelmi hatványhoz jutott, mely ugyanazt a személyt, mint fogalmat vagy célt szubjektíven kizárja és pótolja."

A befolyásolás pszichológiai jellemzőiről írva a presztízs mellett a tekintélyt említi: „A lelki uralomnak valóban két kiterjedése van, vertikális és horizontális, tekintély és presztizs. Sokszor valamely egyénnek vagy csoportnak mindkettóben része van, de ez esetben is mindkettőnek más-más feltételezettsége van (a $+\mathrm{x})$, - az együttmaradás még csak nem is szükségszerú, nemhogy azonosságot jelentene."

Érdekes részletet olvashatunk a vademberek előítéleteiről, amely azonban mai szemmel olvasva inkább a szerző, vagy még inkább a kor elő́téleteit tükrözi. „Sőt még a kannibálizmust is mentik a presztizzsel; sokszor, mondják, azért eszik meg a vadak az ellenséget, mert azt hiszik, hogy így bátorságát örökölni fogják; később ugyane céllal fogyasztják el ellenségük szemét vagy szívét. Mindezek a szeszélyes változások a vadakra vonatkozólag elegendő valószínüséggel magyarázhatók meg. A vadember előítéletei nem jelentkeznek folyton egyazon aktualitással; ugráló hangulatai, szökellő érzelmei, melyek annyira jellemzik, kiszámíthatatlanná teszik magaviseletének minden mozzanatát."

Kornis Gyula „Okság és törvényszerűség a psychologiában” címú 1911-es munkájában (1911b) a pszichológia mint tudomány nehézségeit ecsetelve a lelki élet kettősségét is bemutatja. Sőt a lelki élet ambivalenciája okozza azt a tényt Kornis szerint, hogy a lelki élettel foglalkozó tudomány nem sorolható egyértelműen a természettudományok közé, bár a célja az egyetemesítés, mégsem rendelkezik olyan eszközökkel, amelyek objektív oksági viszonyokat tudnának megállapítani a 
lelki tevékenységre nézve. Ugyanis az okság nem ragadható meg közvetlenül, hanem csak a lelki történések egymásutánjából következtet rá az egyén. Az így kikövetkeztetett oksági kapcsolatok viszont egyáltalán nem különböznek a külső jelenségek objektív oksági viszonyaitól.

Amíg a lelki folyamatok, vagy másképpen a "gondolatélmények" oksági viszonyban állnak egymással, a "gondolattartalmakra" a racionális viszony jellemző. Vagyis a gondolkodás a logikára épül, az élmények, a lelki múködés pedig az egymásból következésre, az asszociációra. Az élmények egészlegessége tulajdonképpen a lelki hatás, amely nem tudatosan irányítja az egyén viselkedését:

„A psychologiában minden fogalomnak sanctióját az élmény kölcsönzi; itt minden fogalom elsősorban phaenomenalis értelemben igaz. Élményeink útján mitsem tudunk arról, hogy bizonyos praesentativ tudatmozzanatok, melyeket a többitől abstrahálva, képzeteknek nevezünk, érzelmektől kisérve complexekbe egyesülnek, tudtunk nélkül elménkben megmaradnak $s$ tudatunk folyamára állandó befolyást gyakorolnak, melyről nincsen - csak eredményében - tudomásunk."

Emiatt írja Kornis az "Elemi pszichológiai kisérletek (1911a) c. munkájában, hogy az introspekciós módszer és a kísérletezés amelyet korábban két tudománynak tekintettek - kiegészítik egymást. Az introspekció fontosságát mutatja például az objektív módon vizsgált tanúvallomások megbízhatatlanságának lelki-oksági magyarázata.

Ehhez a történetiségében megismerhető lelkioksági magyarázathoz tartozik hozzá az a fontos tény is, hogy az ember célkitűző lény, aki az előre eltervezett gondolatait valósítja meg.

\section{3. Összegzés: a korai magyar pszichológia filozófiai-társadalomtudományi hagyományú emberképe}

$A z$ intézményesülés előtti álláspont egy olyan emberképet vázol fel, amely szerint a gondolkodás és a lelki tevékenység egymástól megkülönböztethető és eltérő módon múködnek. A gondolkodás magasabb rendú agyi folyamat, a logika törvényeire épül, az értelem, az ítéletalkotás és az okosság építik fel. Ugyanilyen magasabb szintú funkció az érzékelés és az akarat. Ezzel szemben a lelki tevékenység funkciói az ábrázolás, az érzelmek átélése és a tárgyak által kiváltott vonzódás, illetve taszítás, ezek alacsonyabb rendú múködések. Ide sorolható még az emlékezés és a szokások is.

Az ember lelki tevékenysége aktív, szemben a test passzivitásával. Az aktivitás lehetőségét a lelki tehetség biztosítja, amely öröklött vagy tanult lehet. Az aktivitás feltétele a lélek ereje. A lélek vagy más néven tudat legfontosabb feladata az ábrázolás - mai szóhasználatban az észlelés -, ebből eredeztethető az érzés, amely a tárgyak olyan ábrázolása a tárgy jelenléte nélkül - vagyis az emlékezés a tárgyra -, amely szubjektív és pontatlan.

A különválasztható lelki és gondolkodási funkciók elképzelése után az 1900-as évektől megváltozik az emberről alkotott pszichológiai kép. A lelki tevékenységeket - sőt a testi és a lelki életet - a továbbiakban egységesként képzelik el, amely kiegészül azzal a teleológiai aspektussal is, hogy az ember célkitúző lény, minden lelki és testi tevékenységét a célszerűség határozza meg.

A lelki tevékenységek központjában továbbra is az élmény áll, amely azonban az elvárással összefonódik. A lélek észleli a meglévő és az elvárt közötti különbséget. Ez az észlelt különbség az alapja minden magasabb rendú megismerési folyamatnak, mint a képzetalakítás (amelyet korábban az ábrázolás fogalma fedett le), az emlékezés (amely korábban alacsonyabb rendű funkcióként szerepelt) és az ítéletalkotás (amely korábban a gondolkodás logikai képességéhez tartozó funkció volt).

Érdekes párhuzam figyelhető meg az ember saját belső múködéséről való tudását tekintve. A korábbi nézet szerint a lelki aktivitás idézi elő, hogy az ember tudja, bizonyos benne, hogy van lelke. Az 1900-as évek elképzelése szerint az 
ember a lelki és egyáltalán az életfolyamatai célszerúségét ismeri fel, illetve látja be. Ennél még pregnánsabb az az elképzelés, hogy az ember visszakövetkeztet a lelki tevékenységeire, amelyek között így oksági kapcsolatokat fedez fel. És bár a gondolattartalmak között racionális viszony áll fenn, a gondolatélmények között a kikövetkeztetett oksági viszony áll csak rendelkezésre az ember számára.

A filozófiai-társadalomtudományi gondolkodásban három ponton összegezhető az emberképben bekövetkezett változás. A legfeltúnőbb a lelki tevékenységek különválaszthatóságáról szóló nézetnek az átalakulása a lelki élet egységes elképzelésére. A második változás az egyes funkciók magasabb vagy alacsonyabb rendú besorolásában mutatkozik meg, végül a harmadik változás az ember belső múködéséről származó tudásának elképzelésében következik be, amely tulajdonképpen a közvetlentől - a lelki aktivitás tapasztalása - tolódik a közvetett - az oksági viszonyok következtetése - felé.

\section{FELHASZNÁLT IRODALOM}

[1.] Bárkán György (1985) A pszichológia szerepe a századelő magyar társadalomtudományi megújulásában. Magyar Pszichológiai Szemle, 42. 471-494. o.

[2.] Joó Tibor (1929) Egy kiadatlan régi magyar lélektan. Magyar Psychologiai Szemle, 2/1-2.

[3.] Kornis Gyula (1911a) Elemi pszichológiai kisérletek. Budapest, Franklin

[4.] Kornis Gyula (1911b) Okság és törvényszerúség a psychologiában. Budapest, Franklin

[5.] Leopold Lajos (1912/1987) A presztizs. Budapest, Magvető

[6.] Pataki Ferenc (1977) A magyar pszichológia történeti útjának néhány időszerű tanulsága. Magyar Pszichológiai Szemle, 34. 563-586. o.

[7.] Pikler Gyula (1901) A lelki élet fizikája. A pszikhofiziológia teljes rendszerének vázlata és az uralkodó tan kritikája. Különlenyomat a Huszadik Század 1901. februári számából. Budapest, Politzer Zsigmond és fia kiadása

[8.] Pikler Gyula (1909) A lélektan alapelvei: Az élmény megmaradása és ellentétessége. Budapest, Grill

[9.] Pikler Gyula (1910) A lelki élet alaptörvényei. Az eszmélet helye a természetben. Budapest, Sziklai Jenő kiadása

[10.] Pléh Csaba (1998) Hagyomány és újítás a pszichológia történetében. Budapest, Balassi

[11.] Posch Jenő (1913) Játék, múvészet és munka. Különlenyomat a Magyar Filozófiai Társaság Közleményei 1913/2. számából. Budapest, Magyar Filozófiai Társaság

[12.] Ribot, Th. (1896) A lelki átöröklés. Budapest, MTA

[13.] Romsics Ignác (2002) Magyarország története a XX. században. Budapest, Osiris 